\title{
PERSISTENT ORGANIC POLLUTANS (POPS) DAN KONVENSI STOCKHOLM
}

\author{
Lina Warlina (warlina@mail.ut.ac.id) \\ Universitas Terbuka
}

\begin{abstract}
Persistent organic pollutants (POPs) are toxic chemicals that adversely affect human health and the environment around the world. Because they can be transported by wind and water, most POPs generated in one country can affect people and wild life far from where they are used and released. They persist for long periods of time in the environment and can accumulate and pass from one species to the next through the food chain. To address this global concern, many countries in the world joined forces with 90 other countries and the European Community to sign a groundbreaking United Nations treaty in Stockholm, Sweden, in May 2001, known as the Stockholm Convention. One of important agreement is all countries agreed to reduce or eliminate the production, use, and/or release of 12 key POPs. The Convention specifies a scientific review process that could lead to the addition of other POPs chemicals of global concern. POPs include a range of substances that include intentionally produced chemicals currently or once used in agriculture, disease control, manufacturing, or industrial processes. Also it can be produced by unintentionally produced chemicals, such as dioxins, that result from some industrial processes and from combustion (for example, municipal and medical waste incineration and backyard burning of trash).
\end{abstract}

Key words : POPs, persistent, toxic chemicals, Stockholm Convention

Dalam beberapa dekade terakhir ini, masyarakat dunia telah mengembangkan secara luas kurang lebih 100.000 bahan kimia sintetis yang digunakan untuk mengendalikan penyakit, meningkatkan produksi pangan, dan memberikan kenyamanan dalam kehidupan sehari-hari, dan terjadi penambahan 1500 bahan kimia baru setiap tahunnya (UU No.19 tahun 2009). Teknologi kimia modern telah memproduksi berbagai jenis senyawa kimia, diantaranya yang relatif resisten (tahan) terhadap degradasi secara fisik atau metabolit, yang disebut senyawa kimia persisten. Dewasa ini masalah bahan kimia yang persisten tersebut terutama bahan organik telah menjadi perhatian dunia yaitu Persistent Organic Pollutants (POPs). Senyawaan ini juga sangat berbahaya bagi kesehatan manusia, hewan dan tumbuhan karena sifat negatifnya. Selain dari alam, POPs juga dapat dihasilkan dari sampingan industri, seperti senyawa kimia dioksin/furan, atau dari industri itu sendiri, seperti DDT (Dichloro Diphenyl Trichloroethane).

POPs ditemukan hampir di semua tempat, baik dalam makanan, lahan, air dan udara, pada lingkungan dan manusia di seluruh bumi. POPs dapat terbawa air dan angin serta dapat menyebabkan kerugian. POPs beresiko karena karakteristiknya yang beracun, menetap dan akumulatif pada tubuh manusia, mamalia laut dan hewan lainnya serta dapat menurun dari induk ke janin. POPs dapat bergerak dengan jarak sangat jauh melalui angin dan arus air. 
Apakah yang disebut POPs? POPs adalah senyawa kimia organik yang toksik dan persisten, yang diproduksi untuk bahan pertanian dan industri, atau dari hasil sampingan pembakaran dan proses industri. Sebagai contoh adalah PCBs (Policlorinated Biphenyls) yang merupakan industri kimia; aldrin, dieldrin atau DDT yang dikenal sebagai pestisida; serta dioksin atau furan yang merupakan hasil sampingan industri. Contoh rumus kimia dari senyawaan tersebut adalah seperti pada Gambar 1. Umumnya, senyawaan-senyawaan tersebut mengandung unsur chlor (Cl).

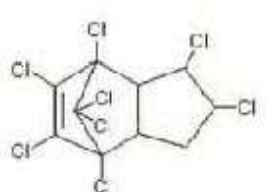

Heptachlor (insecticide)

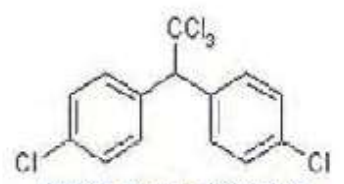

DDT (insecticide)
Dieldrin (insecticide)
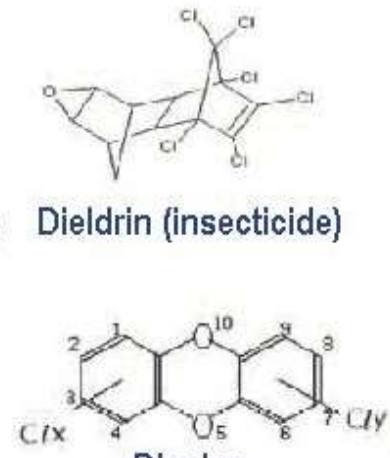

Dioxins

Gambar 1. Contoh rumus kimia senyawaan POPs

PCBs biasa digunakan dalam industri plastik, cat, lem, sistem perpindahan panas, kertas dan komponen listrik. Produksi PCBs sudah dihentikan dan direlokasi ke negara-negara berkembang, karena sifatnya yang toksik dan persisten (Effendi, 2003). Tidak semua pestisida sebenarnya bersifat persisten dan toksik. Hanya pestisida yang termasuk golongan organoklorin yang berbahaya yaitu aldrin, chlordane, dieldrin, DDT, endrin, heptaklor, heksakloro benzene dan mirex, sedangkan dioksin dan furan merupakan hasil sampingan dari industri besi, mineral dan pembakaran tak terkendali.

Negara-negara di dunia semakin sadar bahwa POPs telah mengancam kesehatan manusia dan lingkungan. Puncak dari keperihatinan ini yaitu dengan ditandatanganinya Konvensi Stockholm tentang POPs di Swedia pada tanggal 21-23 Mei 2001 yang dikenal juga dengan POPs Treaty. Konvensi ini bertujuan untuk melindungi kesehatan manusia dan lingkungan dari pencemaran senyawa organik persisten. Dibutuhkan kesanggupan dari negara-negara lain agar upaya internasional untuk memusnahkan POPs dari bumi ini dapat dilaksanakan dengan baik. Pemerintah Indonesia turut menandatangani konvensi ini dan saat ini sedang menyusun Rencana Pelaksanaan Nasional untuk mengelola POPs sesuai persyaratan konvensi. Selama ini sebagian besar masyarakat Indonesia belum terlalu peduli terhadap pencemaran POPs dan belum mengetahui dampak negatif POPs terhadap lingkungan hidup dan kesehatan manusia, khususnya kelangsungan hidup generasi yang akan datang. Dengan demikian tujuan dari tulisan ini adalah memberi pengetahuan kepada masyarakat terhadap masalah bahaya POPs yang tanpa disadari berada di sekeliling kita. 


\section{Efek POPs bagi Kesehatan}

POPs dapat membahayakan kesehatan manusia dan lingkungan karena bahan kimia ini dapat menyebabkan kanker, alergi dan merusak susunan saraf (baik sentral ataupun peripheral). POPs juga dapat mengganggu sistem endokrin yang menyebabkan kerusakan pada sistem reproduksi dan sistem kekebalan yang terjadi pada mahluk hidup, termasuk janin (Matsushita, 2003). adalah:

Karakteristik POPs yang dapat memberikan efek negatif menurut Gorman \& Tynan (2003),

- Terurai sangat lambat dalam tanah, udara, air dan mahluk hidup serta menetap dalam lingkungan untuk waktu yang lama

- Masuk dalam rantai makanan dan dapat terakumulasi pada jaringan lemak, sehingga sukar larut dalam air

- Dapat terbawa jauh melalui udara dan air

Karena karakteristik tersebut, maka sering ditemukan konsentrasi POPs yang sangat tinggi dalam berbagai spesies pada level yang tinggi dari rantai makanan, seperti pada ikan paus, burung elang dan mamalia, termasuk manusia. Perpindahan POPs pada jarak jauh tersebut melalui 3 tahap yang disebut sebagai grasshopper effect (Matsushita, 2003) yaitu evaporasi, perpindahan dalam atmosfir, dan kondensasi pada suhu rendah. Bila evaporasi rendah pada suhu yang lebih dingin, konsentasi POPs cenderung tinggi, seperti di daerah artic dan ekosistem pegunungan.

Di dalam tubuh, POPs akan terakumulasi dalam jaringan lemak. Walaupun dalam konsentrasi yang sangat kecil, tapi jenis pencemar ini akan berakumulasi, sehingga lama kelaman konsentrasinya semakin tinggi, sehingga akan bersifat bioakumulatif dan biomagnifikatif. Berdasarkan penelitian, paparan utama POPs adalah melalui makanan. Sebagai contoh, paparan dioksin di Belanda diperkirakan 95\% berasal dari makanan (Greenpeace, 2009). Salah satu contoh POPs adalah dioksin/furan. Dioksin/furan yang masuk ke tanah berpotensi terserap akar tanaman, dan melalui rantai makanan sampai ke mahkluk hidup. Pada penelitian NIEHS (2001), dioksin/furan mempengaruhi sel sama seperti kerja estrogen. Mekanisme masuknya dioksin ke dalam tubuh seperti pada Gambar 2.

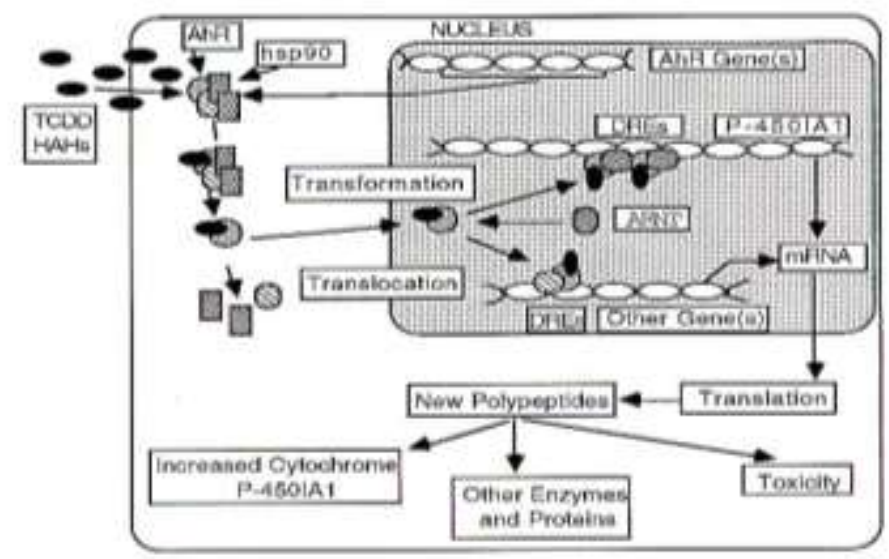

Sumber: http://www.dioxins.nl/Difference/related_info_diff/related_IMG/Calux_diff.gif

Gambar 2 Mekanisme masuknya dioksin ke dalam tubuh 
Dioksin atau disebut juga TCDD (Tetra Chloro Dibenzo p-Dioksin) berikatan dengan protein yang ada pada sel yang disebut reseptor Ah (AhR) membentuk senyawa kompleks bersama dengan translocating protein. Senyawa kompleks ini masuk ke dalam inti sel (nucleus), dan berikatan dengan DNA (Deoxyribo Nucleic Acid) pada tempat yang spesifik dan diikuti dengan translokasi m-RNA (messenger-Ribose Nucleic Acid). Senyawa kompleks ini akan mempengaruhi gen-gen lain, misalnya P-450IA1. Protein berikatan dengan molekul asing, lalu protein tersebut dimetabolisme untuk dikeluarkan dari tubuh, terjadi translokasi pada metabolit, terbentuk protein baru. Sebagian metabolit ini akan menjadi toksik dan sebagian lagi menjadi karsinogen yang aktif. Kanker yang disebabkan dioksin antara lain dapat berupa kanker paru-paru, kanker hati dan sebagainya, terlebih lagi dapat menyerang fungsi reproduksi (Gambar 3).

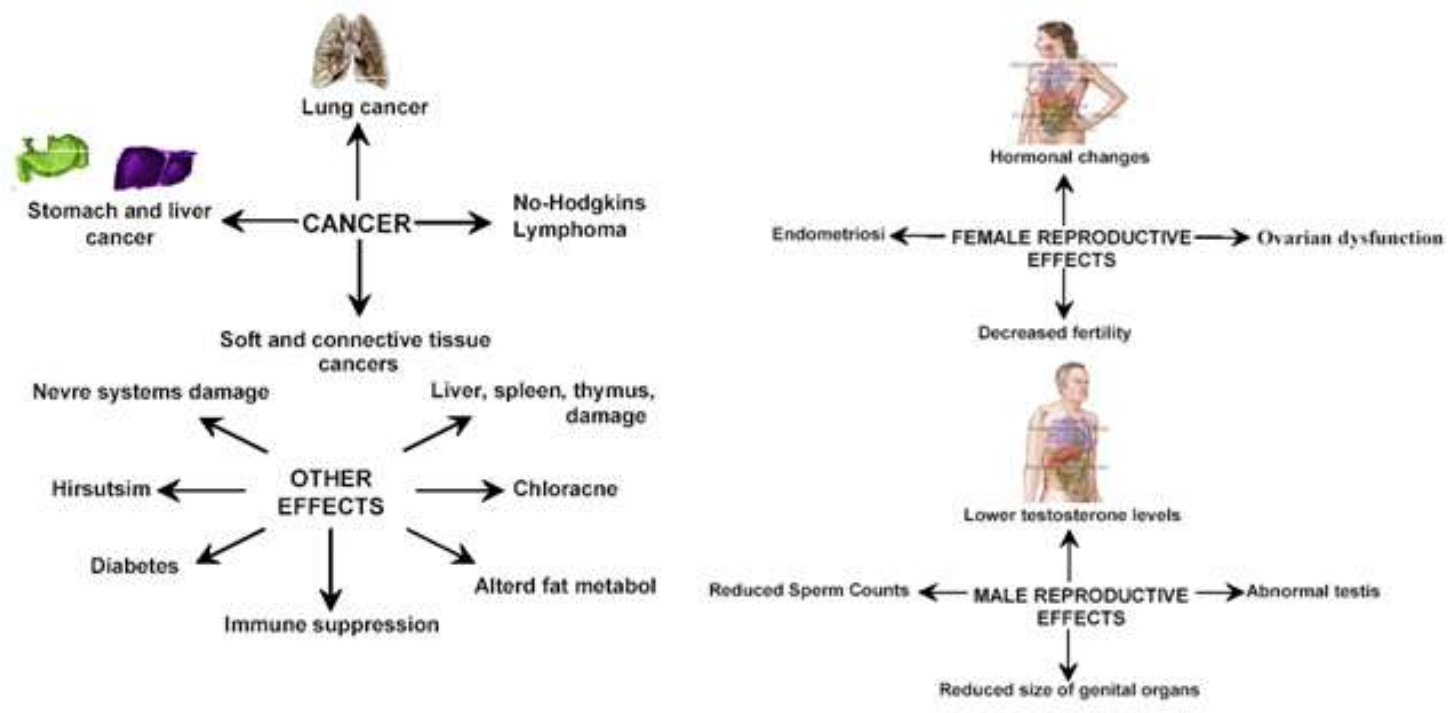

Sumber: Otles \& Yildis (2003)

Gambar 3. Pengaruh dioksin terhadap kesehatan

\section{Jenis dan Penggunaan POPs}

Karena berbagai kebutuhan, maka senyawa-senyawa organik yang walaupun telah diketahui berpotensi membahayakan kesehatan dan lingkungan, masih tetap diproduksi dan dikembangkan, misalnya senyawa organik persisten. Kata persisten masih belum dapat didefinisikan secara tepat sekali. Terminologi persisten seharusnya merujuk kepada sifat kimianya, bukan sekedar keberadaannya pada jaringan tertentu atau penyebaran geografis. Sebagai contoh adalah, PCBs dapat lenyap dari perairan, terakumulasi dalam ikan, lalu ke burung atau mamalia. Lenyapnya PCBs tersebut bukanlah berarti bahwa PCBs tersebut tidak persisten.

Menurut Konvensi Stockholm, yang termasuk jenis POPs adalah 12 jenis bahan kimia yaitu delapan (8) jenis pestisida yaitu aldrin, chlordane, DDT, dieldrin, endrin, heptachlor, mirex dan toxaphene; dua (2) bahan kimia industri yaitu polychlorinated biphenyls (PCB) dan hexachlorobenzene (HCB); dan dua (2) produk sampingan yang tak disengaja yaitu dibenzo-p-dioxin 
dan dibenzofurans (PCDD/PCDF) yang harus dieliminasi, dilarang ataupun dikurangi. Zat-zat POPs tersebut dikelompokkan menjadi 3 kelompok, yaitu:

1. Zat-zat POPs yang sengaja diproduksi seperti pestisida

2. Zat-zat POPs yang diproduksi dan terlepas secara tak sengaja sebagai akibat kegiatan manusia

3. Zat-zat POPs yang digunakan untuk pengendalian vektor penyakit seperti malaria (DDT)

Penggunaan POPs yang utama adalah (US EPA, 2009):

- Aldrin - pestisida yang digunakan untuk membunuh anai-anai, belalang, hama akar jagung dan hama serangga lain

- Chlordane - digunakan secara ekstensif untuk mengendalikan anai-anai dan sebagai broad spectrum obat pembasmi serangga pada lahan pertanian

- DDT - digunakan secara luas pada PD (Perang Dunia) II untuk membasmi malaria, pembasmi tipus dan penyakit lain yang disebar serangga. Selanjutnya digunakan pada beberapa negara untuk mengendalikan malaria

- Dieldrin - digunakan untuk mengendalikan anai-anai dan hama tekstil, digunakan pula untuk mengendalikan penyakit insect borne dan serangga yang hidup di lahan pertanian

- Endrin - obat pembasmi serangga yang disemprotkan pada daun-daun tanaman panenan, dipakai juga untuk mengendalikan tikus dan binatang penggerek lain

- Heptachlor - digunakan untuk membunuh anai-anai dan serangga lahan, serta membunuh serangga kapas, belalang, hama panen lain, dan nyamuk malaria

- Heksaclorobenzene (HCB) - digunakan untuk membunuh jamur tanaman panenan serta dilepaskan dari pembuatan bahan kimia tertentu

- Mirex - obat pembasmi serangga dipakai untuk menyerang semut api, dan jenis lain anai-anai dan semut, digunakan pula sebagai suatu penghambat api dalam plastik, karet, dan barang elektrik

- Toxaphene - obat pembasmi serangga ini disebut juga camphechlor, digunakan untuk kapas, butir gandum, buah-buahan, kacang, dan sayur

- Polyclorinated biphenil (PCBs) - campuran ini digunakan dalam industri sebagai cairan pertukaran panas, di dalam kapasitor dan trafo elektris, dan sebagai aditif dalam cat, kertas karbon, dan plastik

- Dioxins - diproduksi tanpa disengaja dalam pembakaran tak sempurna, seperti halnya sepanjang pembuatan pestisida tertentu dan bahan kimia lain. Sebagai tambahan jenis tertentu untuk pendauran ulang logam, serta pulp dan kertas. Ditemukan pula dalam mobil tua, asap tembakau dan asap kayu dan batubara

- Furan - diproduksi tanpa sengaja dari proses yang sama dengan dioksin dan juga ditemukan pada campuran PCBs komersial.

\section{Pandangan Internasional terhadap POPs}

Menurut International POPs Elimination Network (IPEN), perhatian dunia terhadap POPs diawali dari United Nation Conference on Environment and Development (UNCED) di Rio pada 1992 dan adopsi Agenda 21 Dunia (IPEN, 2001). Pada Mei 1995, Governing Council of the United Nations Environment Program (UNEP) mengeluarkan keputusan (Decision) 18/32 tentang POPs. Pertemuan tersebut dihadiri oleh International Programme on Chemical Safety (IPCS), kerjasama program dari International Labour of Organisation (ILO), the World Health Organisation (WHO) dan UNEP, serta Intergovernmental Forum on Chemical Safety (IFCS) beserta gugus kerjanya untuk memprakarsai suatu penaksiran yang tepat terhadap POPs. Keputusan 18/32 tersebut bertujuan untuk : 
- $\quad$ konsolidasi informasi POPs, menganalisa jalur yang dilewati dan sumbernya, serta pernyataan substansi POPs pada skala global

- memeriksa sumber, resiko, manfaat, dan pertimbangan lain yang relevan dengan produksi dan penggunaan POPs

- mengevaluasi keberadaan POPs, termasuk biaya dan keefektifan penggantian senyawa yang lebih baik yang dapat digunakan

- membuat strategi serta kebijakan mengenai POPs

- mempertimbangkan kondisi negara-negara berkembang serta negara-negara dalam kondisi ekonomi transisi dalam menaksir respon secara realistik.

Pertemuan-pertemuan mengenai POPs terus dilakukan hingga puncak dari kepedulian internasional terhadap POPs adalah Konvensi Stockholm untuk POPs pada tanggal 21-23 Mei 2001 yang ditandatangani oleh 90 negara.

\section{- Konvensi Stockholm tentang POPs}

Konvensi ini bertujuan untuk melindungi kesehatan manusia dan lingkungan dari pencemaran POPs dengan melakukan tindakan bersama untuk mengurangi, menghilangkan secara bertahap pelepasan POPs dari produksi, penggunaan secara sengaja maupun tidak sengaja serta dari tempat penyimpanan dan limbah. Konvensi menghasilkan tulisan dan lampiran yang terdiri dari 30 pasal serta Annex A, B, C, D, E, dan F. Secara garis besar isi Konvensi Stockholm yang penting adalah :

- Pasal 3,5 dan 6 mencakup mengenai ketentuan pengedaran POPs

- Pasal 7 tentang kewajiban negara-negara peserta untuk menyusun Rencana Pelaksanaan Nasional (RPN) atau National Implementation Plan dalam jangka waktu 2 tahun setelah pemberlakuan prioritas kegiatan.

- Pasal 12 berkaitan dengan bantuan teknis

- Annex A, B, C yang memuat 12 jenis bahan kimia POPs

Konvensi juga mengharapkan negara-negara untuk melihat kebijakan dari negara masingmasing dalam hal POPs, yaitu:

1. menumbuhkan kesadaran pemerintah, swasta ataupun individu

2. memperhatikan penanganan terhadap bahan-bahan kimia terutama POPs

3. membuat standar perlakuan/penggunaan POPs

Konvensi ini lalu direspon oleh World Bank Environment Departement yang akan memfasilitasi kegiatan pengembangan dan implementasi tentang POPs. Proyek ini bertujuan antara lain mencari alternatif penggantian pestisida POPs dengan bahan kimia lain yang lebih aman, atau metode pengurangan pestisida, penggantian DDT dengan senyawa lain yang tidak membahayakan untuk mengontrol malaria dan penyakit lain, mengidentifikasi alternatif pembuangan POPs, serta menumbuhkan kesadaran masyarakat tentang pengaruh POPs terhadap kesehatan manusia dan ekosistem.

Sebagai implementasi dari penandatanganan Konvensi Stockholm tentang POP's, berdasarkan Article 7 (Stockholm Convention on Persistent Organics Pullutans, 2001), tiap-tiap negara diharuskan membuat suatu National Implementation Plan (NIP) atau Rencana Penerapan Nasional (RPN). Dalam RPN dicantumkan rencana jangka panjang maupun jangka pendek untuk mengeliminasi, mereduksi ataupun menghilangkan senyawaan POP's. Negara-negara lain, misalnya, Singapura, Filipina, Cina, Hong Kong, Macau dan sebagainya sudah meratifikasi dan membuat RPN, sedangkan Indonesia hingga saat ini masih memproses RPN tersebut. Seperti di Indonesia, di Cina 
dan Filipina senyawaan POP's khususnya dioksin/furan belum banyak dikenal masyarakat (Reyes, 2005; The People's Republic of China, 2007).

\section{Implementasi Konvensi Stockholm di Indonesia}

Indonesia sebagai negara yang turut menandatangani Konvensi Stockholm harus mengimplementasikan Konvensi tersebut. Dalam rangka penyusunan RPN, pemerintah Indonesia mendapat hibah dari Global Environment Facility (GEF) untuk pelaksanaan Pekerjaan Kegiatan Awal Pelaksanaan Konvensi Stockholm tentang POPs di Indonesia. Pekerjaan berlangsung selama 2 tahun (2002-2004). Selanjutnya, pada bulan Juni 2003, UNIDO (The United Nation Industrial Development Organization) memberikan dukungan penuh atas pelaksanaan lokakarya tentang Sosialisasi Hasil Inventarisasi Bahan Kimia POPs di Indonesia. Output dari inventarisasi bahan kimia POPs antara lain:

- Pestisida organochlorine POPs telah tidak digunakan lagi di Indonesia, dan tidak ada stok yang tersisa di masyarakat ataupun di Instansi Pemerintah (Sumatra \& Utomo, 2003)

- Emisi dioksin dan furan umumnya belum dikenal di Indonesia, walaupuan emisi ini sangat berbahaya. Perkiraan emisi tahun 2000 cukup tinggi yaitu sekitar 21.982 gTEQ (Toxic Equivalent Quotient, satuan yang digunakan untuk dioksin) yang sebagian besar berasal dari pembangkitan tenaga (Suminar, 2003)

Hasil inventarisasi ini akan dituangkan ke dalam RPN dan akan disampaikan pada pertemuan Conference of Parties (COP) dari Konvensi Stockholm. Mengenai kajian tentang peraturan perundang-undangan, kebijakan pembangunan di Indonesia sebenarnya telah mengacu pada pembangunan yang berwawasan lingkungan. Ini dapat terlihat dari komitmen formal dengan diberlakukannya Undang-undang No.4 tahun 1982 tentang Pokok-pokok Pengelolaan Lingkungan Hidup yang direvisi menjadi Undang-undang No. 23 tahun 1997 tentang Pengelolaan Lingkungan Hidup dan direvisi kembali menjadi Undang-undang No. 32 tahun 2009 tentang Perlindungan dan Pengelolaan Lingkungan Hidup.

Untuk kebutuhan pelaksanaan Konvensi Stockholm, Yudomustopo (2003) telah melakukan kajian tentang peraturan perundang-undangan, infrastuktur, dan kelembagaan yang berkaitan dengan cemaran POP's. Berdasarkan hasil inventarisasi perundangan tersebut, instansi-instansi yang terkait dengan peraturan yang berhubungan dengan POP's adalah Kementerian Lingkungan Hidup (KLH) (dalam hal ini Badan Pengelolaan Lingkungan Hidup Daerah, Bapedal), Departemen Pertanian, Departemen Perhubungan, Departemen Tenagakerja, Departemen Kesehatan, dan Departemen Dalam Negeri, serta Departemen Perdagangan. Kajian tersebut menyimpulkan antara lain:

a. Indonesia belum mempunyai peraturan perundang-undangan yang secara khusus mengatur tentang POP's seperti yang diamanatkan oleh Konvensi Stockholm.

b. Kementerian Lingkungan Hidup mempunyai kewenangan yang terbatas untuk merumuskan kebijakan nasional di bidang pengelolaan lingkungan hidup.

c. Pemahaman tentang POP's, belum dikenal secara jelas oleh aparat pemerintah serta di kalangan masyarakat luas termasuk para industriawan.

d. Kapasitas laboratorium sangat bervariasi, tapi belum ada laboratorium yang dapat menganalisis dioksin/furan.

Sebenarnya Indonesia telah mempunyai PP No. 74 tahun 2001 tentang Pengelolaan B3 (Bahan Beracun dan Berbahaya) serta PP No. 18 tahun 1999 tentang Pengelolaan Limbah B3. Berdasarkan undang-undang tersebut, Pemerintah Indonesia telah mengeluarkan berbagai peraturan 
pelaksanaan yang mengatur tentang Bahan Beracun dan Berbahaya (B3). Adapun PP yang mengatur tersebut adalah:

1. PP No. 18 tahun 1999 tentang Pengelolaan Bahan Barbahaya dan Beracun dan telah diubah menjadi PP No. 85 tahun 1999

2. PP No. 74 tahun 2001 tentang Pengelolaan Bahan Berbahaya dan Beracun

Menurut PP tersebut yang dimaksud dengan B3 adalah bahan yang karena sifat dan atau konsentrasinya dan atau jumlahnya, baik secara langsung maupun tidak langsung dapat mencemarkan dan atau merusak lingkungan hidup, kesehatan, kelangsungan hidup manusia serta mahluk hidup lainnya. Sedangkan yang dimaksud dengan pengelolaan B3 adalah kegiatan yang menghasilkan, mengangkut, mengedarkan, menyimpan, menggunakan dan atau membuang bahan berbahaya dan beracun.

Peraturan Pemerintah No. 74 tahun 2001 yang diundangkan pada tanggal 26 November 2001 memuat 43 Pasal dan 2 (dua) Lampiran, yaitu daftar B3 yang dipergunakan dan daftar B3 yang dilarang dipergunakan. Berdasarkan daftar ini, bahan kimia POP's yang dilarang adalah aldrin, chlordane, DDT, dieldrin, endrin, heptachlor, mirex, toxaphene, hexachlorobenzene serta PCBs. Dioksin/furan belum termasuk yang dilarang penggunaannya. Sedangkan dalam PP No. 18 tahun 1999, pada pasal 34 mengenai pengolahan limbah B3, disebutkan bahwa pada pengolahan secara thermal dengan insinerator, maka efisiensi penghilangan dioksin/furan harus mencapai 99,999\%.

Selain itu, pemerintah telah mengeluarkan UU RI No. 19 tahun 2009 tentang pengesahan Stockholm Convention on Persistent Organics Pollutants (Konvensi Stockholm tentang Bahan Pencemar Organik yang Persisten). UU ini dimaksudkan untuk mengesahkan Konvensi Stockholm dimana Indonesia pada saat itu (tahun 2001) turut menandatanganinya. Indonesia berkewajiban untuk mengikuti kesepakatan yang terdapat pada Konvensi tersebut, salah satunya adalah perlunya dilakukan pengelolaan yang berwawasan lingkungan terhadap bahan pencemar tersebut serta pencegahannya. Konvensi Stockholm mengikat Indonesia untuk mengadopsi berbagai ketentuan konvensi tersebut sebagai hukum nasional untuk dijabarkan dalam kerangka peraturan dan kelembagaan, antara lain: mengembangkan upaya penggunaan bahan kimia alternatif yang ramah lingkungan dalam proses produksi; mempersiapkan daerah untuk mengelola timbunan residu bahan POPs dan melakukan pengawasan dan pemantauan; memperkuat penegakan hukum; dan mengembangkan RPN.

\section{PENUTUP}

POPs adalah senyawa kimia organik yang toksik dan persisten, yang diproduksi untuk bahan pertanian dan industri, atau dari hasil sampingan pembakaran dan proses industri. Ke 12 jenis POPs, yaitu aldrin, chlordane, dieldrin, heptachlor, hexachlorobenze, mirex, toxaphene, dan PCB tidak boleh digunakan. DDT penggunaannya diperbolehkan dengan pengawasan ketat, sedangkan dioksin, furan dan hexachlorobenzene merupakan hasil samping dari produksi atau pembakaran. Senyawaansenyawaan ini tanpa kita sadari banyak berada di sekeliling kita dan dapat menimbulkan dampak negatif bagi lingkungan dan kesehatan. Pemerintah Indonesia telah mulai peduli dengan pencemaran POPs. Walaupun demikian, masyarakat masih belum terlalu mengenal pencemaran ini, sehingga perlu ditumbuhkan kesadaran bagi masyarakat akan bahayanya pencemaran ini, misalnya dengan sosialisasi. Hal ini dimaksudkan, demi kelangsungan hidup bagi generasi yang akan datang. 


\section{REFERENSI}

Effendi, H. (2003). Telaah kualitas air bagi pengelolaan sumber daya dan lingkungan perairan. Yogyakarta: Penerbit Kanisius.

Gorman, S., \& Tynan, E. (2003). Environment strategy notes: Persistent organics pollutants- a legacy of environmental harm and threats to health. No. 6 May 2003. Diambil 23 Februari 2004, dari situs http://www.worldbank.org/pops

Greenpeace. (2009). What are persistent organic pollutants?. Diambil 31 Juli 2009, dari situs http://www.greenpeace.org/international/campaigns/toxics/toxic-hotspots/what-are-persistentorganic-po

http://www.dioxins.nl/Difference/related_info_diff/related_IMG/Calux_diff.gif Diambil 23 Februari 2004

IPEN (The International POPs Elimination Network). (2001). The POPs Handbook for the Stockholm Convention on Persistent Organic Pollutants. Diambil 23 Februari 2004, dari situs http://www.oztoxics.org/research/pops/pop_cover.html

Matsushita, M. (2003). Enabling Facilities to Facilitate Early Action on Implementation of the Stochkolm Convention on Organics Pollutants (POPs) in Indonesia, makalah pada Workshop Sosialisasi Hasil Inventarisasi Bahan Kimia POPs di Indonesia. Jakarta: KLH.

NIEHS (National Institute of Environmental Health Sciences). (2001). Dioxin research at the National Institute of Environmental Sciences (NIEHS). Diambil 4 Oktober 2004, dari situs http://www.niehs.nih.gov/oc/factsheets/dioxin.htm

Otles, S., \& Yildiz, H. (2003). Dioxin in food and human health. Electron. J. Environ. Agric. Food Chem. 2(5):593-608. Diambil 10 Maret 2008, dari situs http://ejeafche.uvigo.cs/index.php?option=com_docman\&task=doc_view\&gid=222

Stockholm Convension on Persistent Organics Pollutants. (2001). Diambil 23 Februari 2004, dari situs http://www.pops.int/documents/convtext/convtext_en.pdf,

Sumatra, M., \& Utomo, S.W. (2003). Inventarisasi Pestisida Organochlorine dan Polychlorinated Biphenyls (PCBs). Makalah pada Enabling Facilities to Facilitate Early Action on Implementation of the Stochkolm Convention on Organics Pollutants (POPs) in Indonesia, Workshop Sosialisasi Hasil Inventarisasi Bahan Kimia POPs di Indonesia. Jakarta: KLH.

Suminar, SA. (2003). Estimasi emisi dioksin dan furan. Makalah pada Enabling Activities to Facilitate Early Action on the Implementation of the Stockholm Convention on Persistent Organic Pollutants (POPs) in Indonesia. Workshop Hasil Inventarisasi POPs. UNIDO. Jakarta: KLH.

Reyes, AT. (2005). Final national implementation plan for Stockholm Convention on POPs. Diambil 21 November 2007, dari situs http://www.pops.int/documents/implementation/nips/submission/NIP_Philippines.pdf .

The People's Republic of China. (2007). National implementation plan for the Stockholm Convension on persistent organic pollutants. Diambil 21 November 2007, dari situs http://www.pops.int/documents/implementation/nips/submission/China_NIP_En.pdf

Yudomustopo, H. (2003). Kajian Tentang Peraturan Perundang-undangan Infrastruktur dan Kelembagaan yang Berkaiatan dengan Cemaran Organik Persisten (POP), makalah pada Workshop Sosialisasi Hasil Inventarisasi Bahan Kimia POPs di Indonesia. Jakarta: KLH.

US EPA. (2009). Persistent Organic Pollutants: A Global Issue, A Global Response. Diambil 26 Juli 2009, dari situs World Wide Web http://www.epa.gov/oia/toxics/pop.htm\#affect 
Undang-Undang Republik Indonesia No. 19 Tahun 2009. Tentang Pengesahan Stockholm Convention on Persistent Organics Pollutants (Konvensi Stockholm tentang Bahan Pencemar Organik yang Persisten). 